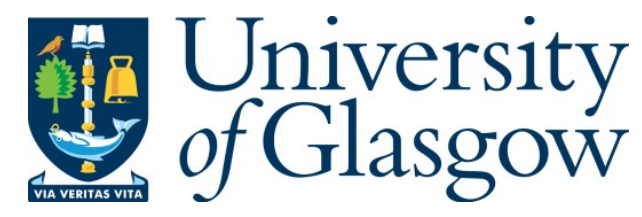

A bdel W ahab, A ntar, A bul M aaty, M ostafa A ., Stuart, Finlay M ., A wad, Hesham, and K afafy, A ziz (2014) The geology and geochronology of Al Wahbah maar crater, Harrat Kishb, Saudi Arabia. Quaternary Geochronology, 21 . pp. 70-76. ISSN 1871-1014

Copyright @ 2014 Elsevier

A copy can be downloaded for personal non-commercial research or study, without prior permission or charge

Content must not be changed in any way or reproduced in any format or medium without the formal permission of the copyright holder(s)

When referring to this work, full bibliographic details must be given

http://eprints.gla.ac.uk/92452/

Deposited on: 11 M arch 2014

Enlighten - Research publications by members of the U niversity of Glasgow http://eprints.gla.ac.uk 


\section{The geology and geochronology of Al Wahbah maar crater, Harrat Kishb, Saudi Arabia.}

Antar Abdel Wahab ${ }^{1}$, Mostafa A. Abul Maaty ${ }^{1}$, Finlay M. Stuart ${ }^{2}$, , Hesham Awad $^{1}$, Aziz Kafafy ${ }^{1}$

${ }^{1}$ Geology Research Unit, P.O. Box 888, Taif University, Taif 21974, Kingdom of Saudi Arabia.

${ }^{2}$ Isotope Geosciences Unit, Scottish Universities Environmental Research Centre, East Kilbride, G75 0QF, United Kingdom.

*Author for correspondence: email: fin.stuart@glasgow.ac.uk 


\section{Abstract}

Al Wahbah is a large ( 2.2 km diameter, $\sim 250 \mathrm{~m}$ deep) maar crater in the Harrat Kishb volcanic field in western Saudi Arabia. It cuts Proterozoic basement rocks and two Quaternary basanite lava flows, and is rimmed with an eroded tuff ring of debris from the phreatomagmatic explosion that generated the crater. A scoria cone on the northern wall of the crater was dissected by the explosion and exposes a dolerite plug that was intruded immediately prior to crater formation. The dolerite plug yields $\mathrm{a}^{40} \mathrm{Ar} /{ }^{39} \mathrm{Ar}$ age of $1.147 \pm 0.004 \mathrm{Ma}$. This is the best possible estimate of the time Al Wahbah crater formed. It is a few tens of thousand years younger than the age of the lower and upper basalt flows, $1.261 \pm 0.021 \mathrm{Ma}$ and $1.178 \pm 0.007 \mathrm{Ma}$ respectively. A dolerite dyke exposed within the basement in the wall of the crater is dated at $1.886 \pm 0.008 \mathrm{Ma}$. This is the most precise age so far determined for the initiation of basaltic volcanism of Harrat Kishb, and confirms that it is significantly younger than the other post-rift volcanic provinces in the region. This study provides constrains the timing of humid climatic conditions in the region and suggests that the Quaternary basaltic volcanism that stretches the length of the western side of the Arabian peninsula may prove to be useful for establishing palaeoclimatic conditions.

Keywords: Saudi Arabia, maar crater, phreatomagmatic, ${ }^{40} \mathrm{Ar} /{ }^{39} \mathrm{Ar}$ age

\section{Introduction}

The western margin of the Arabian peninsula is covered by approximately 180,000 $\mathrm{km}^{2}$ of Cenozoic to Recent basalt flows and related volcanic rocks. The volcanic 
fields stretch from Yemen to northern Syria and are comprised dominantly of alkali olivine basalts and hawaiites that were erupted onto Neoproterozoic crust of the Arabian-Nubian shield. Volcanism started in the late Oligocene to early Miocene, slightly earlier than the main stage of continental extension that has subsequently produced the Red Sea Rift (Coleman et al. 1983; Camp and Roobol, 1989).

Several major volcanic fields (termed harrats) occur throughout the western part of the Kingdom of Saudi Arabia (KSA) (Figure 1). A series of seminal studies of these lava fields was undertaken in the late 1980s and early 1990s by the Saudi Arabian Directorate General of Mineral Resources (Camp \& Roobol, 1989; 1991; 1992, Camp et al. 1991; 1992, Roobol and Camp 1991). The largest volcanic fields form a $600 \mathrm{~km}$-long north-south oriented trend that may be related to an underlying rift zone within the Proterozoic basement (Figure 1). This trend, called the MakkahMadinah-Nafud (MMN) volcanic line (Camp et al. 1991), links Harrat Rahat in the south with Harrat Khaybar and Harrat Ithnayn in the north. The MNN line is a rift zone that has been extending at approximately $0.05 \mathrm{~mm} /$ year for the last 10 million years.

The volcanic fields are dominantly composed of mildly alkalic basalts (olivine basalt and alkali olivine basalt) and lesser amounts of fractionated products. Volcanism may have migrated northwards with time (Camp \& Roobol, 1989; Camp et al. 1991). Harrat Kishb lies approximately $100 \mathrm{~km}$ east of the MMN line, and Harrats Kura, Raha, and 'Uwayrid are a similar distance to the west. These fields are dominated by basalts that are more strongly alkalic than those of the MMN line. The compositional contrast with the adjacent fields implies that they originate from 
melting at different P-T conditions than those from the MMN line. The MMN basalts were probably derived from greater degrees of partial melting, at shallower depths (Camp and Roobol, 1992).

The timing of volcanism is constrained from several $\mathrm{K}-\mathrm{Ar}$ age determinations of basalts from all the main volcanic fields (Camp \& Roobol, 1989, Camp et al. 1991; 1992). In a compilation of published and unpublished basalt ages, Moufti et al. (2012) show a general increase in the number of basalts erupted over the past 10 million years. This implies that the eruption rate is increasing with time. This may be, in part, an artifact of sampling, and does not necessarily reflect the volume of basalt erupted, but it serves to underline that the region remains volcanically active. The most recent basalt eruption in KSA occurred in $1256 \mathrm{AD}$ at the northern end of Harrat Rahat where a $23 \mathrm{~km}$-long basaltic lava flow came within a few kilometers of the holy city of Al Madinah (Camp et al. 1987).

Climatic conditions across the Arabian peninsula have fluctuated between wet and dry extremes several times throughout the Quaternary and have had a profound effect on environment and the development of human populations in the region (e.g. Thompson, 2000). However, the existing chronological constraints on the climatic changes are poor. Precise determination of when key volcanic features formed has the potential to refine the climatic and environmental evolution of the region.

The harrats of KSA contain numerous tuff rings and maar craters that were produced by phreato-volcanic activity. They maars clearly formed at a time when surface water was more abundant than now, and the climate was considerably more 
humid. Al Wahbah crater in Harrat Kishb is the only maar that is not filled with erupted material, sediments derived from wall rocks and wind-borne dust. It is likely to be the youngest maar in the region, and certainly the most spectacular maar in the region (Figure 2). It has a significant place in regional folklore, often called Makla Tameya. Here we present a new study of the geology of Al Wahbah maar crater, combined with the first high precision geochronology of the local volcanic rocks in order to place much-needed constraints on the palaeoclimate history of the region.

\section{The geology of Al Wahbah crater}

Al Wahbah crater $\left(41^{\circ} 08^{\prime} 299^{\prime \prime} \mathrm{E}, 22^{\circ} 54 ; 040^{\prime \prime} \mathrm{N}\right)$ is located in western part of the Harrat Kishb volcanic field. Harrat Kishb is approximately $6,000 \mathrm{~km}^{2}$ and is the youngest of the volcanic fields in KSA, the earliest lavas being erupted approximately 1.5 million years ago (Camp et al. 1992). The morphologically youngest flows do not appear to have relicts of Neolithic animal husbandry so must have been erupted in the last 4,000 years (Camp et al. 1992). The volcanism of Harrat Kishb is coeval with the harrats to the west and has a similar north-south oriented central vent system. However, the lavas are more undersaturated and significantly more alkalic than the other harrats. The basalts are predominantly basanite and alkali olivine basalt in composition, with a small proportion of fractionation products; olivine transitional basalt to phonolite (Camp et al. 1992). Xenoliths of mantle peridotite and pyroxenite have been found in Harrat Kishb and are consistent with a model of asthenosphere upwelling beneath the Red Sea rift (e.g. Kuo and Essene, 1986; McGuire, 1988). 
Sahl and Smith (1986) divided the volcanic rocks of southern Harrat Kishb into three formations: the Unayyizah Formation (seven sub-divisions: two Tertiary-Quaternary and five Quaternary), the overlying Quaternary Waabah and Hil formations. Camp et al. (1992) identify three main volcanic units, from oldest to youngest they are the Diakah, Nafrat and Hil basalts. Al Wahbah crater has been excavated into Lower Hil basalts (Camp et al. 1992).

Al Wahbah (Figure 2a) is the largest of five basaltic tuff rings in Harrat Kishb. The crater geology was briefly described in Camp et al. (1992) and in a short article in a popular science magazine (Grainger, 1996). It is located at the western edge of the province, while the other four are aligned approximately north-south in the centre of the field. The crater is elliptical in shape, measuring between 2,300 and 1,750 metres, with long axis oriented NNW (Figure 2b). It is approximately 250 metre deep. The crater diameter and height/diameter ratio are typical of the range recorded by maar craters. The crater is filled with material that has eroded from the crater walls and wind-blown dust. The central part of the crater floor surface is covered by a large patch of gypsum polygons that overlie gypsum-bearing mud deposit. The salt pan has precipitated from an ephemeral lake that forms briefly after intermittent rainfall (Figure 2a).

A partially eroded tuff ring forms the rim of the crater. The crater is excavated from two basaltic lava flows that total 50-60 metres in thickness and approximately 180 metres of basement rocks from Neoproterozoic Arabian-Nubian shield (Johnson et al. 2011). The basement is largely comprised of undeformed medium-grained 
dioritic granite and gabbro that is probably the Ediacaran-aged Hadb ash Sharar suite (Johnson, 2006). It is intruded by several 1 - 3 metre thick undeformed dolerite dykes that are related to the Harrat Kishb volcanism. They are typically mediumgrained, with small phenocrysts of plagioclase, clinopyroxene and rare olivine.

The basalts that overlie the basement are massive and display prominent columnar jointing. The lower flow is a 30 metre-thick olivine-phyric hawaiite. The upper flow is 5 - 10 metres thick. It contains sparse phenocrysts of olivine and plagioclase, and rare small clinopyroxene. Occasional corroded granite xenoliths are present in this unit. Both flows belong to sub-unit Qh3 of the Lower Hil basalts of Harrat Kishb (Camp et al. 1992). The petrography of the Harrat Kishb basalts is described in detail by Camp et al. (1992).

The tuff ring sits directly on the highly vesiculated top of the upper basalt flow, indicating that the phreato-magmatic eruption that generated the crater occurred rapidly after the eruption of the upper flow. The tuff is poorly sorted and weakly lithified. It is approximately $5 \mathrm{~m}$ thick at the crater rim and thins away from the rim for several hundreds of metres. Fragments of basement lithologies, dolerite and basalt, as well as olivine and augite crystals, are embedded in fine-grained matrix. Clasts are up to a few tens of centimeters in the basal parts of the deposit. These grade upwards into sand-sized clasts in the upper layers. Vesicles are filled by colloidal silica, zeolite and carbonate. The tuff is laminated and displays prominent dune-bedding.

A 80 metre high scoria cone sits on top of the upper lava at the north western side of 
the crater . The cone has been dissected by the explosion that formed the crater and exposes clear stratigraphic relationships within the volcanic sequence. Both of the basaltic lavas are cut by the neck of the magma that fed the scoria cone (Figure 2c). Below the scoria cone a $\sim 300$ metre wide plug of dolerite is exposed in the crater wall. The scoria deposit grades into the tuff deposit with no significant discontinuity. This suggests that the two are genetically related and implies that the locus of eruption moved into the crater area prior to phreatomagmatic eruption. Hyaloclastic deposits and pillow basalts are abundant at the base of the scoria cone demonstrating that prior to the phreatomagmatic stage the vent erupted into standing water, probably a shallow lake. The phreatomagmatic explosion appears to been located approximately 1 kilometre to the southeast. This likely occurred in response to magma migration along a fissure eruption into the lake, or groundwater in an aquifer beneath it.

The age of Al Wahbah crater has not been determined directly and can only be deduced by bracketing. It must be younger than the upper lava flow that formed the pre-crater land surface beneath the blast deposits, and older than a morphologically young basaltic lava that has flowed up against the tuff ring on the northeastern side (Figure 2b). The basanite flows beneath the base-surge deposits belongs to subunit Qh3 of the Hil basalt. No age determinations have been made on Qh3 basalts. Camp et al. (1992) report a K-Ar age of $1.55 \pm 0.61 \mathrm{Ma}$ for a Qh2 basalt of Harrat Kishb. Kemp et al. (1982) and Berthier et al. (1981) report ages of between 1.24 Ma and 0.7 Ma for Qh2 basalts but no uncertainties are provided to allow the precision of the data to be assessed. The morphologically young basalt flow that post-date the maar formation belongs to sub-unit Qh6 of the Hil formation. It lacks the 
Neolithic monuments that are common on all the older lava surfaces, and it is likely that it post-dates the Neolithic, and is younger than the last pluvial period in the region, implying an age less than $\sim 5 \mathrm{ka}$. Thus all that can be said with clarity is that the crater formed some time in the last 2 million years.

Major and trace elements have been determined on samples of the dolerite neck below the scoria cone, the upper and lower basalt lavas and a dolerite dyke (Supplementary data 1). Measurements were made by X-ray fluorescence spectrometry at the Geological Survey of Saudi Arabia.

The Al Wahbah volcanism has total alkali $\left(\mathrm{K}_{2} \mathrm{O}+\mathrm{Na}_{2} \mathrm{O}\right)$ content in the range 5.4 to 7.3 wt. \%. This is high compared to the basalts from Harrat Rahat, Harrat Kura and Harrat Khaybar-Ithyayn that form the MNN line (Camp and Roobol, 1989, Camp et al. 1991). They define a differentiation trend on a TAS diagram (Figure 3) that, with the exception of the dyke, overlaps the earlier measurements of Harrat Kishb basalts (Camp et al. 1992). In common with the majority of the Hil formation basalts, they plot in the basanite field on the TAS diagram. The total variation in $\mathrm{MgO}$ in the $\mathrm{Al}$ Wahbah rocks is large $(6.2-9.3 \mathrm{wt} . \%)$ and is a significant proportion of the total compositional range of the Harrat Kishb hawaiite-basanite suite $(\mathrm{MgO}=5.7-11.6$ wt.\%; Camp et al. 1992). The major and trace element data is consistent with olivine fractionation being the dominant control on the basalt composition. Sub-ordinate effects are produced by variation in clinopyroxene and plagioclase phenocryst content.

\section{${ }^{40} \mathrm{Ar} /{ }^{39} \mathrm{Ar}$ geochronology of Al Wahbah volcanic activity}


We have made high precision ${ }^{40} \mathrm{Ar} /{ }^{39} \mathrm{Ar}$ age determinations on samples of the main volcanic units of the crater sequence in order to place chronological constraints on the eruption of the Hil formation basalts in the Harrat Kishb. Samples of the lower lava flow (AW-2), the upper lava flow (AW-14) and the dolerite intrusion beneath the scoria cone (AW-16) have been dated in order to determine the age of Al Wahbah maar crater. The age of the dolerite dyke $(\mathrm{AW}-10)$ was determined in order to provide constraints on maximum duration of volcanism in the Harrat Kishb.

Altered material was first removed from each sample and the remaining fresh material was crushed. The 125-250 um fraction was washed in de-ionized water then passed through a magnetic separator to remove olivine and pyroxene phenocrysts and then leached in $10 \% \mathrm{HNO}_{3}$ in an ultrasonic bath six times. Phenocryst-free groundmass grains were hand-picked under a binocular microscope. Approximately $80-100 \mathrm{mg}$ from each sample was packed into small $\mathrm{Cu}$ packets, placed in Al discs, and stacked in a sealed glass vial for irradiation.

The samples were irradiated in the Cd-lined (CLICIT) facility of the Oregon State University TRIGA reactor for 180 seconds. Alder Creek sanidine (ACs: $1.193 \mathrm{Ma}$; Nomade et al., 2005) and Fish Canyon sanidine (FCs: 28.02 Ma; Renne et al., 1998) was used to characterize the irradiation flux. The $\mathrm{J}$ values were determined from analysis of 15 single FCs grains in the five different irradiation discs (1 sample per disc; $\mathrm{n}=75$ ). Each crystal was melted with a $\mathrm{CO}_{2}$ laser and $\mathrm{Ar}$ isotopes measured using a MAP 215-50 noble gas mass spectrometer. ACs was measured as an unknown using the $\mathrm{J}$ parameters determined from FCs. Ages for ACs overlap with 
stated ages at $68 \%$ confidence showing the $\mathrm{J}$ parameters determined are suitable for measurement of unknown ages.

The basalts were step-heated in a custom-built scanning $\mathrm{CO}_{2}$ laser. Samples were heated continuously for 5 minutes and sample gases were cleaned for 10 minutes by exposure to 3 GP50 SAES getters (two operated at $450^{\circ} \mathrm{C}$ and one at room temperature) and a cold finger maintained at $-95^{\circ} \mathrm{C}$ for 10 minutes prior to measurement. Gas extraction, clean up and data collection was entirely automated. Argon isotope ratio determinations were made using a MAP 215-50 noble gas mass spectrometer with a measured sensitivity of $1.13 \times 10^{-13}$ moles/volt. Isotope data are corrected for blank, radioactive decay, mass discrimination and interfering reactions. System blanks were measured after every two measurements of unknowns. Average blank measurements \pm standard deviations for the entire run sequence were used to correct raw peak intensities. Mass discrimination was monitored by measurement of air pipettes after every 5 analyses $\left({ }^{40} \mathrm{Ar} /{ }^{36} \mathrm{Ar}: 291.62 \pm 1.15, n=26\right)$. The atmospheric ratios of Lee et al. (2006) that have been independently verified by Mark et al. (2011a) were used to correct data for mass discrimination (D: $1.0059 \pm$ 0.0009) and atmospheric contamination. Plateau and inverse isochron calculations are based on the criteria outlined elsewhere (Mark et al. 2011b).

${ }^{40} \mathrm{Ar} /{ }^{39} \mathrm{Ar}$ data are reported according to the recommendations of Renne et al. (2009) and are presented at $68 \%$ confidence level. To present the most accurate ${ }^{40} \mathrm{Ar} /{ }^{39} \mathrm{Ar}$ age for the Al Wahbah maar crater we have recalculated our age (against Steiger \& Jäger, 1977; Renne et al., 1998) relative to the optimisation model of Renne et al. (2010) using the approach presented in Ellis et al. (2012). ${ }^{40} \mathrm{Ar} /{ }^{39} \mathrm{Ar}$ ages relative to 
Renne et al. $(2010 ; 2011)$ are discussed throughout the rest of this paper and their significance is discussed below. Note that the Renne et al. $(2010 ; 2011)$ optimization model outputs ages and uncertainties including full systematic errors (i.e., standard age and decay constant uncertainty). Consequently the data presented here are fully comparable to ages from other chronometers.

All samples (Supplementary data 2, Figure 4) yield statistically robust $100 \%{ }^{39} \mathrm{Ar}$ plateau ages with inverse isochrons that define initial trapped components of atmospheric composition. Further the inverse isochron ages and plateau ages all overlap at the $68 \%$ confidence level, showing the data to be precise. The plateau ages are systematically in stratigraphic order. The dolerite from the intrusive neck beneath the scoria yields the youngest plateau age $(1.147 \pm 0.004 \mathrm{Ma})$. This is distinct at the $2 \sigma$ level from that the upper basalt flow $(1.178 \pm 0.007 \mathrm{Ma})$. The small age difference between the upper flow and the intrusive neck is consistent with the near pristine flow top features of the upper flow that underlie the tuff produced during the phreatomagmatic eruption. The lower basalt flow $(1.261 \pm 0.021 \mathrm{Ma})$ was erupted $83 \pm 23$ kyr prior to the youngest flow. The dolerite dyke exposed within the basement in the wall of the crater is significantly older $(1.886 \pm 0.008 \mathrm{Ma})$.

\section{Discussion}

Regional volcanic history

Field evidence suggests that the magmatic intrusion that generated the phreatomagmatic explosion probably occurred slightly after the cooling of the 
dolerite that is exposed in the neck of the scoria cone. This was likely part of the same event that erupted the scoria cone. Thus the age of the dolerite from the intrusive neck beneath the scoria provides the best high precision estimate of the timing of the formation of Al Wahbah crater.

We are not aware of age determination of sub-unit Qh3 basalts from the Hil formation of Harrat Kishb. The formation of Al Wahbah crater should slightly postdate the eruption of sub-unit Qh2 basalts that is dated by K-Ar to $1.55 \pm 0.61 \mathrm{Ma}$ (Camp et al. 1992) (Figure 5). The new age significantly refines the timing of crater formation. Further, it resolves the obvious discrepancy in the existing age data, which appear to show that the Lower Narfat lavas are significantly younger than the Hil formation basalts (Figure 5). The precise ages of the Qh3 Hil basalts at Al Wahbah imply that the Lower Narfat ages of Camp et al. (1992) are too young.

The old age of the dolerite dyke confirms the geochemical evidence that it is not the feeder of either of the pre-maar basalt lava flows. Further, it provides, so far, the most precise upper limit on the age of the Harrat Kishb volcanism. To date the best age determination on the initiation of volcanism is that provided by K-Ar ages of the Diakah formation basalts, the oldest in the province $(1.31 \pm 0.36 \mathrm{Ma}$ and $1.48 \pm 0.6$ Ma; Camp et al. 1992) shown in Figure 5. The age of the dyke (1.884 $\pm 0.014 \mathrm{Ma})$ is at the upper end of the existing range though it is significantly more precise and tends to confirm that the basaltic volcanism of Harrat Kishb initiated significantly later than in the volcanic fields that have been erupted along the MMN-line. Precise determination of the Saudi Arabian harrats is now possible with $\mathrm{Ar} / \mathrm{Ar}$, and is 
essential for testing the prevailing geodynamic models of the generation of post-rift volcanism of the region (e.g. Moufti et al. 2012).

The potential of Saudia Arabian maars for palaeoclimatic reconstruction

There is abundant evidence that the climate of the Arabian peninsula has fluctuated between wet and dry conditions during the Quaternary. However, the timing of the palaeoenvironmental changes prior to the Holocene are poorly constrained (Thompson, 2000). Lower Pleistocene lacustrine deposits with extensive fossil record are known from sites in the An Nafud desert in northwest Saudi Arabia (Thomas et al. 1998). Fish and turtle fossils in the deposits imply that water was present all-year round. The carbon isotopic composition of teeth from large herbivores show that they survived on $\mathrm{C} 4$ plants, indicating that open grassland existed. This suggests that the Lower Pleistocene climate was significantly less arid than present day, consistent with the observations from the pre-explosion volcanic rocks at Al Wahbah.

The Arabian peninsula is considered to be a critical location for early human migration out of Africa. The presence of Oldowan-like and Acheulean assemblages may reflect two major (or more) hominim dispersals through the region. Early Palaeolithic stone tool industry sites are known throughout the region, most notably from the margins of modern deserts (see Petraglia, 2005 for review). They may be contemporaneous with Homo erectus occupation and Achuelian assemblages in the Ethiopian depression and southern Red Sea at around 1 million years ago (Asfaw et al. 2002; Schick and Clark, 2003). The significant environmental changes are likely 
to have had a profound effect on the development of human populations in the region (Parker and Rose, 2008). However, there is little absolute chronology of environmental record, and most age information in relation to early humans relies on typotechnological changes.

The work presented here demonstrates that the volcanic fields of the Arabian peninsula are a rich palaeo-environmental record that can be used as absolute. For instance, the presence of pillow basalts at the base of scoria cone on the rim of $\mathrm{Al}$ Wahbah provides clear evidence that a significant body of surface water existed at this time, implying, in turn, that the climate at the time must have been considerably wetter. The sediments that have accumulated in the maar crater clearly have potential to provide a record of the regional history of precipitation and evaporation for the last one million years. Harrat Kishb is one of the smallest volcanic fields of Arabia, yet it has in excess of 100 scoria cones and 7 maar craters that all potentially contain sediment records. Future reconstructions of the Quaternary palaeoenvironmental evolution of the Arabian peninsula should not ignore the volcanic record.

Acknowledgements The authors express their sincere thanks to His Excellency the Taif University Rector, Professor Abdel Elah Banaja, for continuous support and encouragement during all steps of research since its inception. Thanks must go to Dr. Abdul Rahman AlTalhi, Mr Rashid Al Saadi, and the support services people at Taif University who facilitated fieldwork, and to Darren Mark and Dan Barfod for Ar/Ar dating. We thank Profs. John Hora and Brad Singer for thorough reviews that greatly improved this paper. 


\section{References}

Asfaw, B. et al. 2002. Remains of Homo erectus from Bouri, Middle Awash, Ethiopia. Nature 416, 327-320.

Berthier, F., Demange, J., Jundi, F., Verzier, P., 1981. Geothermal resources of the Kingdom of Saudi Arabia: Saudi Arabian Deputy Ministry of Mineral Resources. Open-File Report BRGM-OF-01-24, 116 pp.

Camp, V.E., Roobol, M.J., 1989. The Arabian continental alkali basalt province: Part I, Evolution of Harrat Rahat, Kingdom of Saudi Arabia: Geological Society of America Bulletin, 101, 71-95.

Camp, V.E., Roobol, M.J., 1991. Geological map of Cenozoic lava field of Harrat Rahat, Kingdom of Saudi Arabia: Saudi Arabian Deputy Ministry for mineral Resources Geosciences Map GM-123, scale 1:250,000 with text. (Previously released as Saudi Arabian Deputy Ministry for mineral Resources Open File Report DGMR-OF- 07-9-91p. 1987).

Camp, V.E., Roobol, M.J., 1992. Upwelling asthenosphere beneath western Arabia and its regional implications. Journal of Geophysical Research, 97 B11, 15,25515271.

Camp, V.E., Hooper, P.R., Roobol, M.J., White, D.L., 1987. The Madinah eruption, Saudi Arabia: magma mixing and simultaneous extrusion of the three basaltic chemical types. Bulletin of Volcanology, 49, 489-508.

Camp, V.E., Roobol, M.J., Hooper, P.R., 1991. The Arabian continental alkali basalt province: Part II, Evolution of Harrats Khaybar, Ithnayn, and Kura, Kingdom of Saudi Arabia. Geological Society of America Bulletin 103, 363-391. 
Camp, V.E., Roobol, M.J., Hooper, P.R., 1992. The Arabian continental alkali basalt province: Part III, Evolution of Harrat Kishb, Kingdom of Saudi Arabia. Geological Society of America Bulletin 104, 379-396.

Coleman, R.G., Gregory, R.T., Brown, G.F., 1983. Cenozoic volcanic rocks in Saudi Arabia. Saudi Arabian Deputy Minister of Mineral Resources, Open File Report, USGS-OF93.

Ellis, B.S., Mark, D.F., Pritchard, C.J., Wolff, J.A. (2012) Temporal dissection of the Huckleberry Ridge Tuff using the ${ }^{40} \mathrm{Ar} /{ }^{39} \mathrm{Ar}$ dating technique. Quaternary Geochronology, 9, 34-41.

Grainger, D.G., 1996. Al Wahbah volcanic explosion crater, Saudi Arabia. Geology Today, 12, 27-30.

Johnson, P.R., 2006. Explanatory notes to the map of Proterozoic geology of western Saudi Arabia. Saudi Geological Survey Technical Report SGS-TR2006-4, 62 pp.

Johnson, P.R., Andresen, A., Collins, A.S., Fowler, A.R., Fritz, H., Ghebreab, W., Kusky, T., Stern, R.J. 2011. Late Cryogenian-Ediacaran history of the ArabianNubian Shield: A review of depositional, plutonic, structural, and tectonic events in the closing stages of the northern East African Orogen. Journal of African Earth Sciences 61, 167-232.

Kemp, J., Gross, Y., Prian, J.P. 1982. Geologic map of the Mahd adahab quadrangle, sheet 23E, Kingdom of Saudi Arabia: Deputy Ministry of Mineral Resources, Geoscience Map GM-64, scale: 1:250,000, with text, 39p.

Kuo, L-C., Essene, E.J., 1986. Petrology of spinel harzburgite xenoliths from the Kishb plateau, Saudi Arabia. Contributions to Mineralogy and Petrology, 93, 335-346. 
Lee, J-Y., Marti, K., Severinghaus, J.P., Kawamura, K., Yo, H-S., Nok, J., Kim, J.S., 2006. A redtermination of the isotopic composition of atmospheric Ar.

Geochimica et Cosmochimica Acta 70, 4507-4512.

Mark, D.F., Stuart, F.M., de Podesta, M., 2011a. New high-precision measurements of the isotopic composition of atmospheric argon. Geochimica et Cosmochimica Acta 75, 7494-7501.

Mark D.F., Rice C.M., Fallick A.E., Trewin N.H., Lee M.R., Boyce A., Lee J.K.W.

$2011 \mathrm{~b},{ }^{40} \mathrm{Ar} /{ }^{39} \mathrm{Ar}$ dating of hydrothermal activity, biota and gold mineralization in the Rhynie hot-spring system, Aberdeenshire, Scotland. Geochimica et Cosmochimica Acta 75, 555-569

McGuire, A.V., 1988, Petrology of mantle xenoliths from Harrat al Kishb: the mantle beneath western Saudi Arabia. Journal of Petrology 29, 73-92.

Moufti, M.R., Moghazi, A.M., Ali, K.A., 2012. Geochemistry and Sr-Nd-Pb isotopic composition of the Harrat Al-Madinah Volcanic Field, Saudi Arabia. Gondwana Research 21, 670-689.

Nomade S., Renne P. R., Vogel N., Deino A. L., Sharp W. D., Becker T. A., Jaouni A. R., Mundil, R. (2005) Alder Creek sanidine (AC-s-2): A Quarternary ${ }^{40} \mathrm{Ar} /{ }^{39} \mathrm{Ar}$ dating standard tied to the Cobb Mountain geomagnetic event. Chemical Geology, 218, 315-338

Parker, A.G., Rose, J.I., 2008. Climate change and human origins in southern Arabia. Proceedings of the Seminar for Arabian Studies, 38, 25-42.

Petraglia, M.D., 2005. Hominin responses to Pleistocene environmental change in Arabia and South Asia: in "Early-Middle Pleistocene Transitions: The LandOcean Evidence; eds. M. Head \& P. Gibbard”, London: Geological Society, Special Publication 247, 305-319. 
Renne, P.R., Swisher, C.C., Deino, A., Karner, D.B., Owens T.L., Depaolo, D. 1998, Intercalibration of standards: absolute ages and uncertainties in ${ }^{40} \mathrm{Ar} /{ }^{39} \mathrm{Ar}$ dating. Chemical Geology, 145, 117-152.

Renne, P.R., Deino, A.L., Hames, W.E., Heizler, M.T., Hemming, S.R., Hodges, K.V., Koppers, A.P., Mark, D.F., Morgan, L.E., Phillips, D., Singer, B.S. Turrin, B.D., Villa, I.M., Villeneuve, M., Wijbrans, J.R. 2009, Data reporting norms for ${ }^{40} \mathrm{Ar} /{ }^{39} \mathrm{Ar}$ geochronology. Quaternary Geochronology 4, 346-352.

Renne P.R., Mundil R., Balco G., Min K., Ludwig K.R., 2010 Joint determination of ${ }^{40} \mathrm{~K}$ decay constants and ${ }^{40} \mathrm{Ar} * /{ }^{40} \mathrm{~K}$ for the Fish Canyon sanidine standard, and improved accuracy for ${ }^{40} \mathrm{Ar} /{ }^{39} \mathrm{Ar}$ geochronology. Geochim. Cosmochim. Acta $74,5349-5367$

Renne P.R., Mundil R., Balco G., Min K., Ludwig K.R., 2011 Response to the comment of W.H. Schwarz et al. on "Joint determination of ${ }^{40} \mathrm{~K}$ decay constants and ${ }^{40} \mathrm{Ar}^{*} /{ }^{40} \mathrm{~K}$ for the Fish Canyon sanidine standard, and improved accuracy for ${ }^{40} \mathrm{Ar} /{ }^{39} \mathrm{Ar}$ geochronology." By P.R. Renne et al. 2010 Geochim. Cosmochim. Acta 75, 5097-5100.

Roobol, M.J., Camp, V.E. 1991. Geological map of the Cenozoic lava fields of Harras Khayba. Ithnayen and Kurs, Kingdom of Saudi Arabia: Saudi Arabian Directorate General of Mineral Resources Geosciences Map Gm-131, scale 1:250 000 with text. (Previously released as Saudi Arabian Directorate General of Mineral Resources Open - File report DGMR - OF - 10 - 1. 88p., 1989).

Sahl, M., Smith, J.W., 1986. Geology of the Al Muwayh quadrangle sheet 22E, Kingdom of Saudi Arabia: Saudi Arabian Deputy Ministry for Mineral Resources, Geoscience Map GM-88, 1:250.000 scale with text, 29p. 
Schick, K., Clarke, J.D., 2003. Biface technological development and variability in the Acheulean industry complex in the Middel Awash region of the Afar Rift, Ethiopia. In, Soressi, M., and Dibble, H.L. (eds), Multiple Approaches to the study of bifacial Technologies, University of Pennsylvania Press, 1-30.

Steiger, R.H., and Jäger, E., 1977. Subcommission on geochronology: convention on the use of decay constants in geo- and cosmochronology. Earth \& Planetary Science Letters 6, 359-362.

Thomas, H., et al. 1998. Decouverte des premieres faunes Pleistocene de la peninsule Arabique dans le desert du Nafud (Arabie Saoudite). Compte Rendu de l'Academie des Sciences. 326, 145-152.

Thompson, A. 2000. The origins of Arabia. Stacey International Press, pp. 192. 


\section{Figure captions}

Figure 1. Map showing the main Cenozoic volcanic fields, with ages, of the Arabian peninsula, including Harrat Kishb (modified from Moufti et al. 2011). Dashed lines define the Makkah-Madinah-Nafud line (see text for details).

Figure 2. (a) Photograph of Al Wahbah crater taken from the base of the scoria cone. The show looks south east and shows the two lava flows and tuff ring capping $\sim 200 \mathrm{~m}$ of Proterozoic basement. The salt pan in the centre of the crater floor is gypsum. (b) Satellite image of Al Wahbah crater. (c) Photograph of the dissected section through the scoria cone on the NW side of Al Wahbah crater taken from the floor of the crater.

Figure 3. Plot of $\mathrm{SiO}_{2}$ vs total alkalis for the dyke (white circles) lower and upper lavas from Al Wahbah crater (light grey and mid grey circles respectively), and dolerite neck beneath the scoria cone (dark grey). The shaded field delineates the compositional range defined by all basalts from the Harrat Kishb (Camp et al. 1992).

Figure 4. Age plateau and isotope correlation plots (inverse isochrons) showing the ${ }^{40} \mathrm{Ar} /{ }^{39} \mathrm{Ar}$ ages of the main volcanic units at Al Wahbah crater in Harrat Kishb, Saudi Arabia.

Figure 5. Summary of ${ }^{40} \mathrm{Ar} /{ }^{39} \mathrm{Ar}$ ages of main volcanic units of Al Wahbah crater (light grey circles), and comparison to the K-Ar ages of the main formations (dark grey circles) of Harrat Kishb (Camp et al. 1992). Horizontal lines record the $1 \sigma$ age uncertainties. Where no lines are shown age uncertainties are smaller than the size of the symbol. 


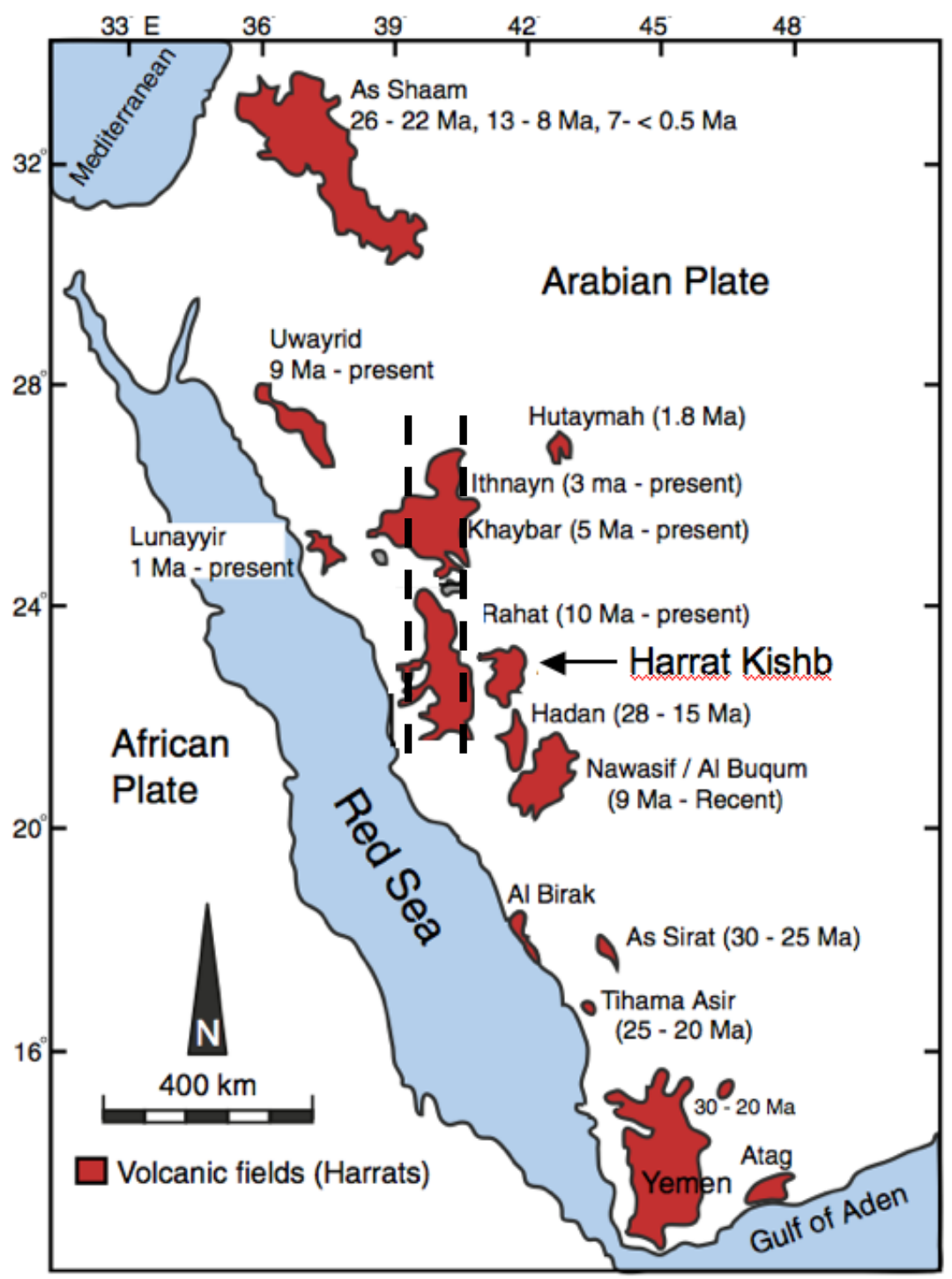

Figure 1 


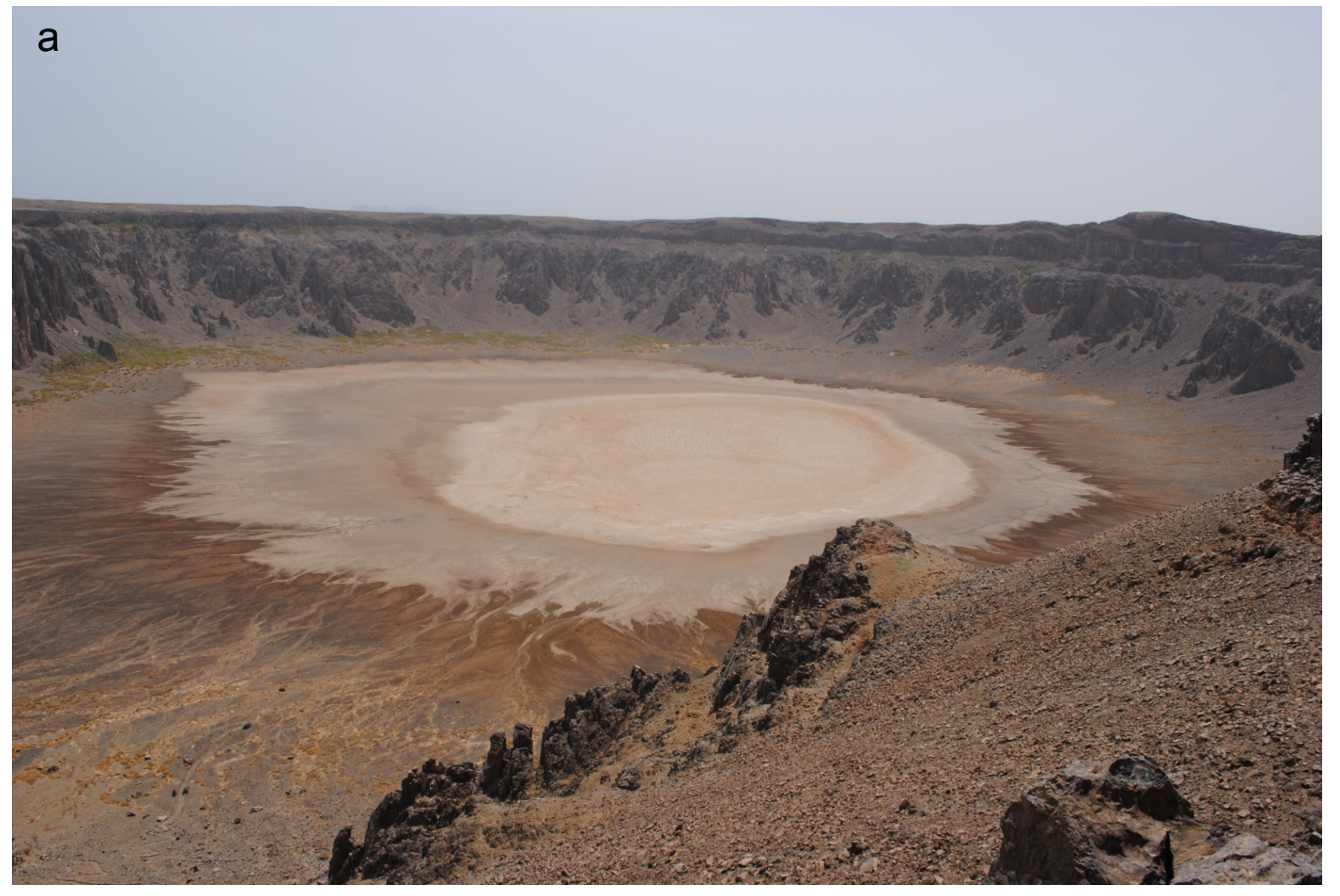

Figure 2a 


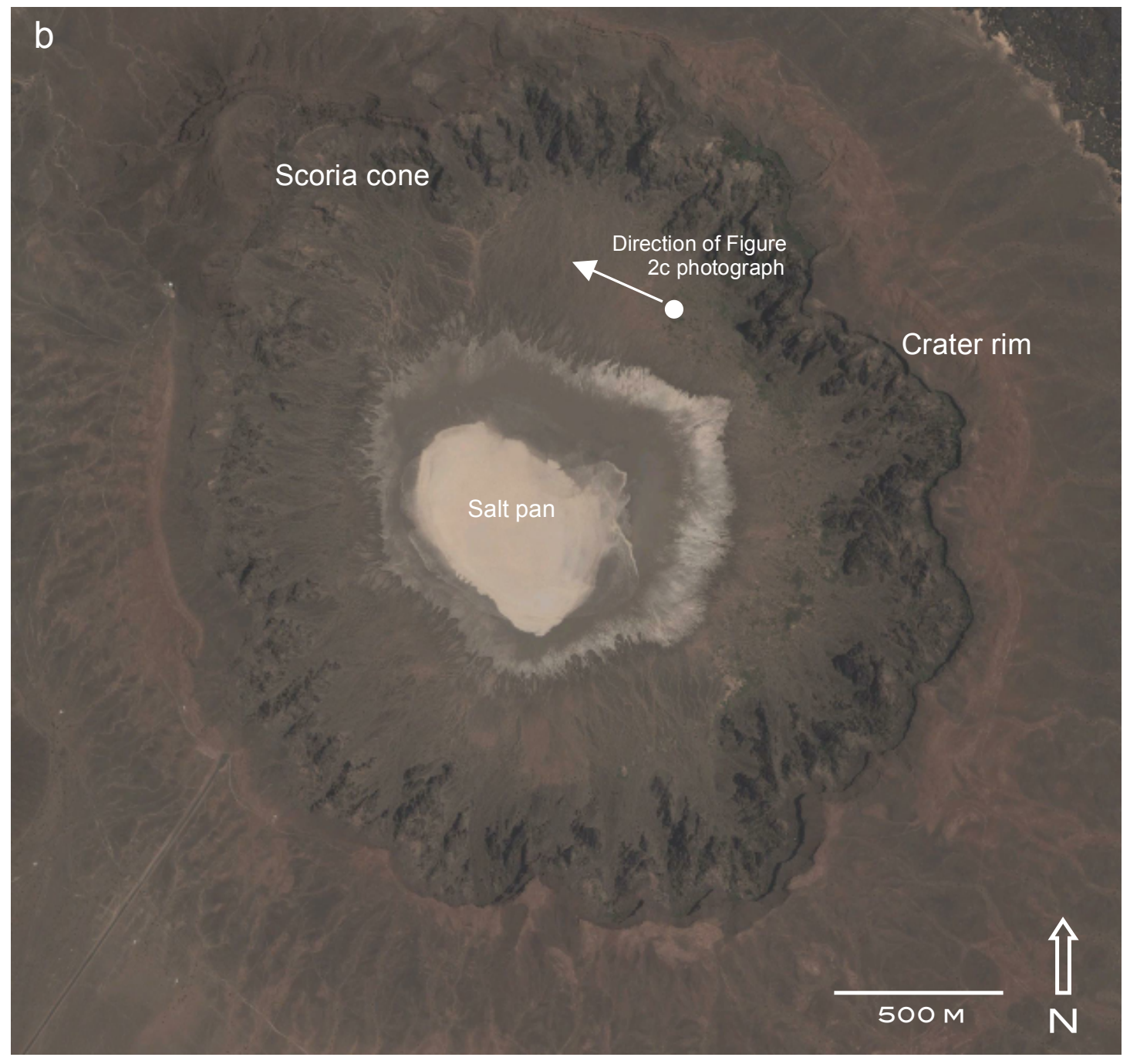

Figure $2 b$ 


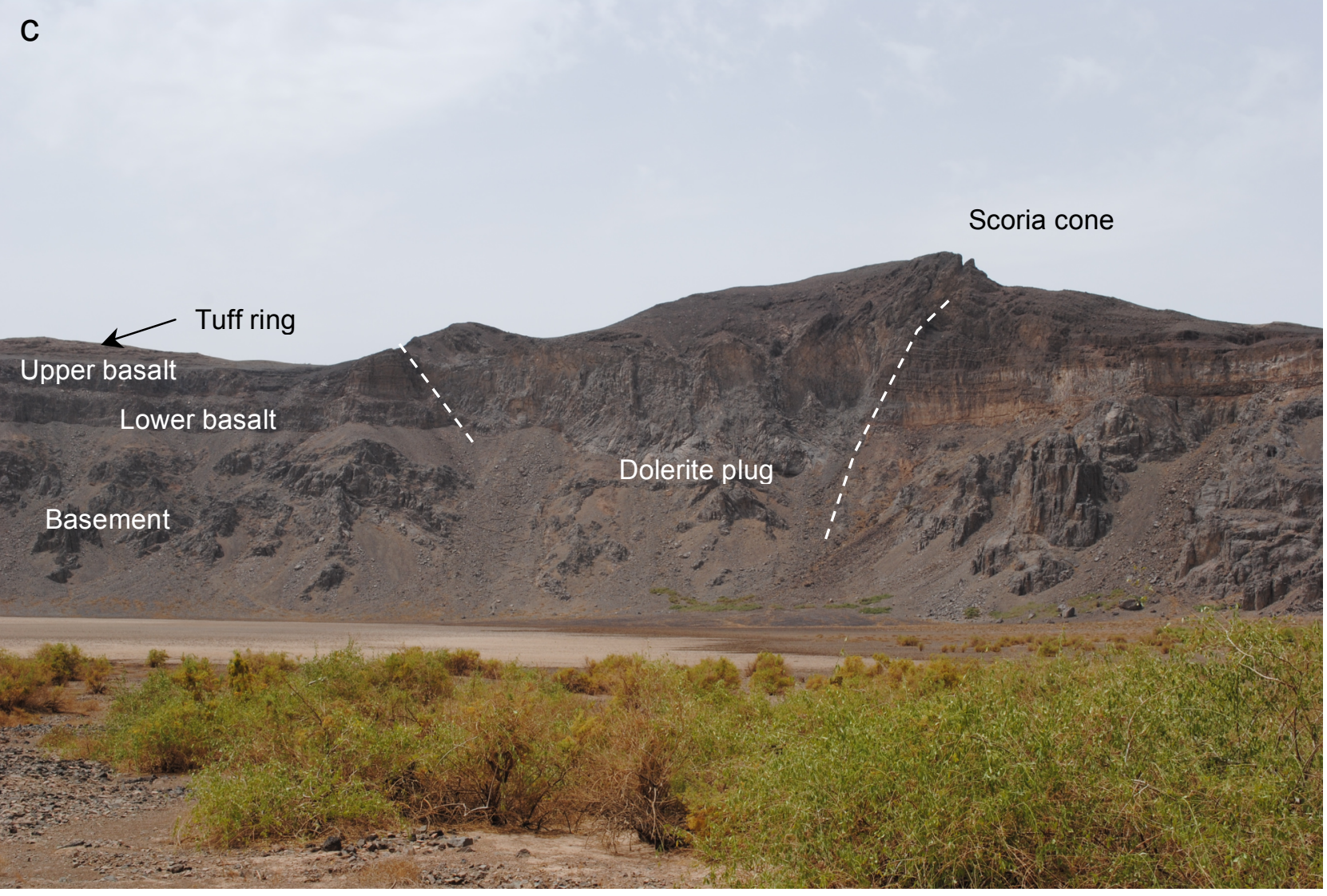

Figure 2c 


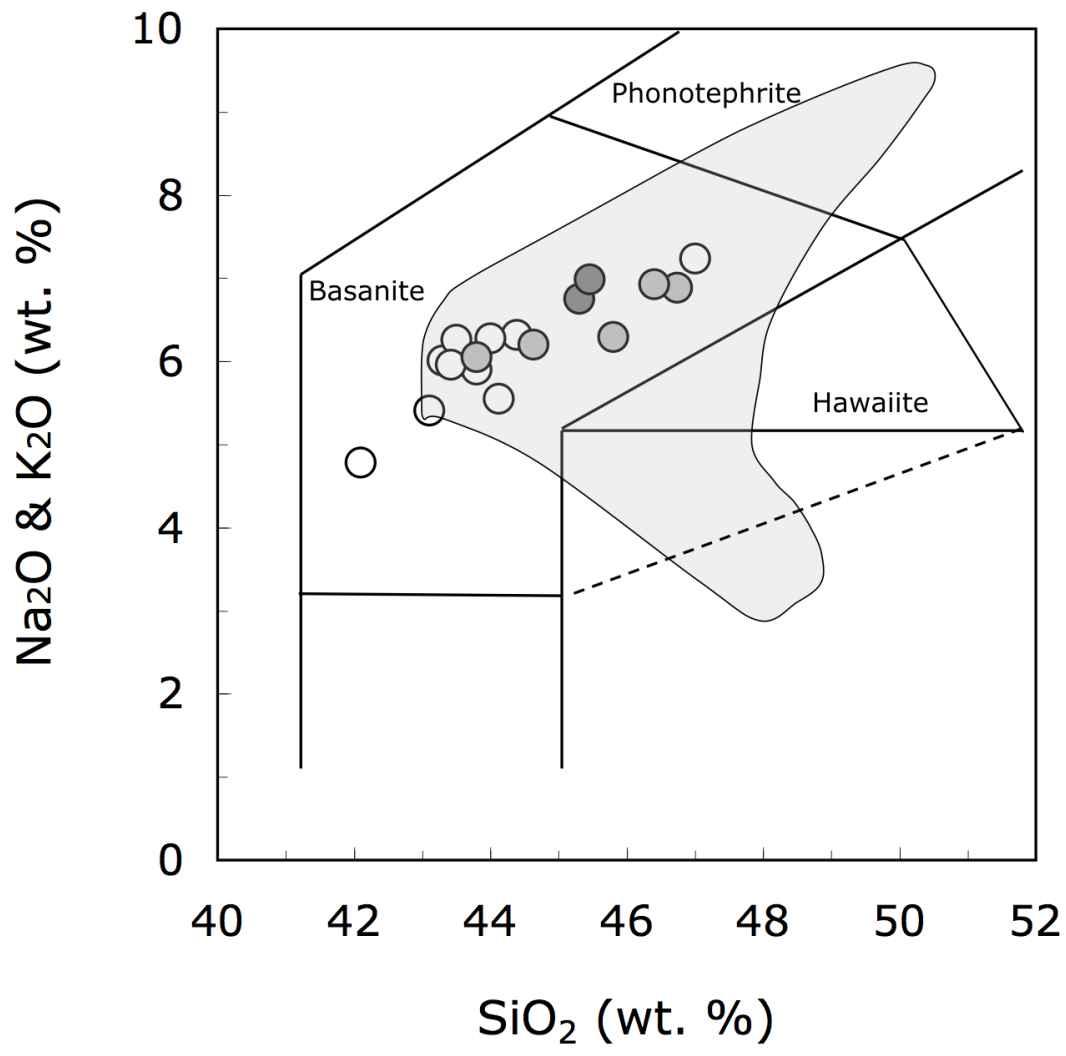

Figure 3 

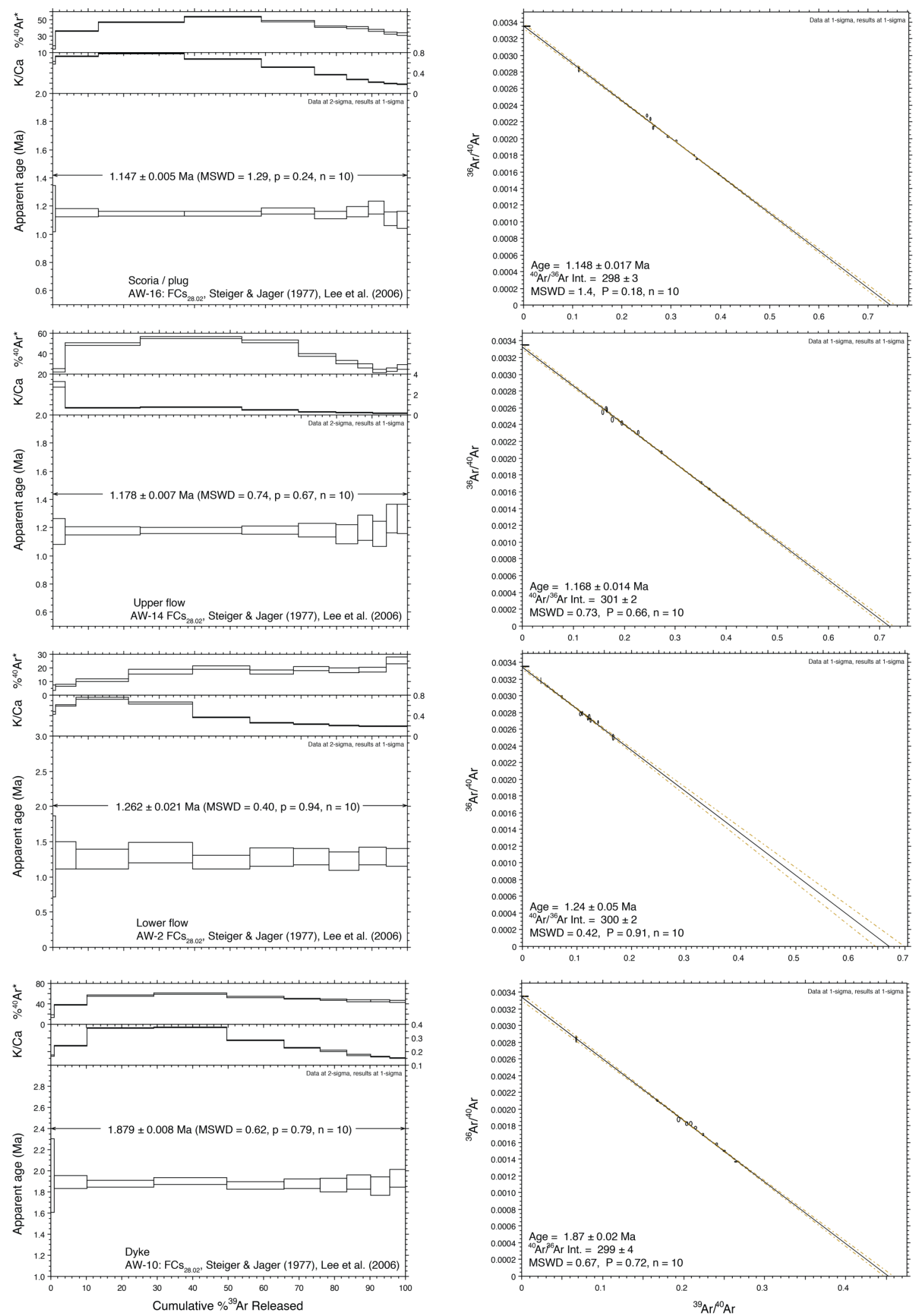

Figure 4 


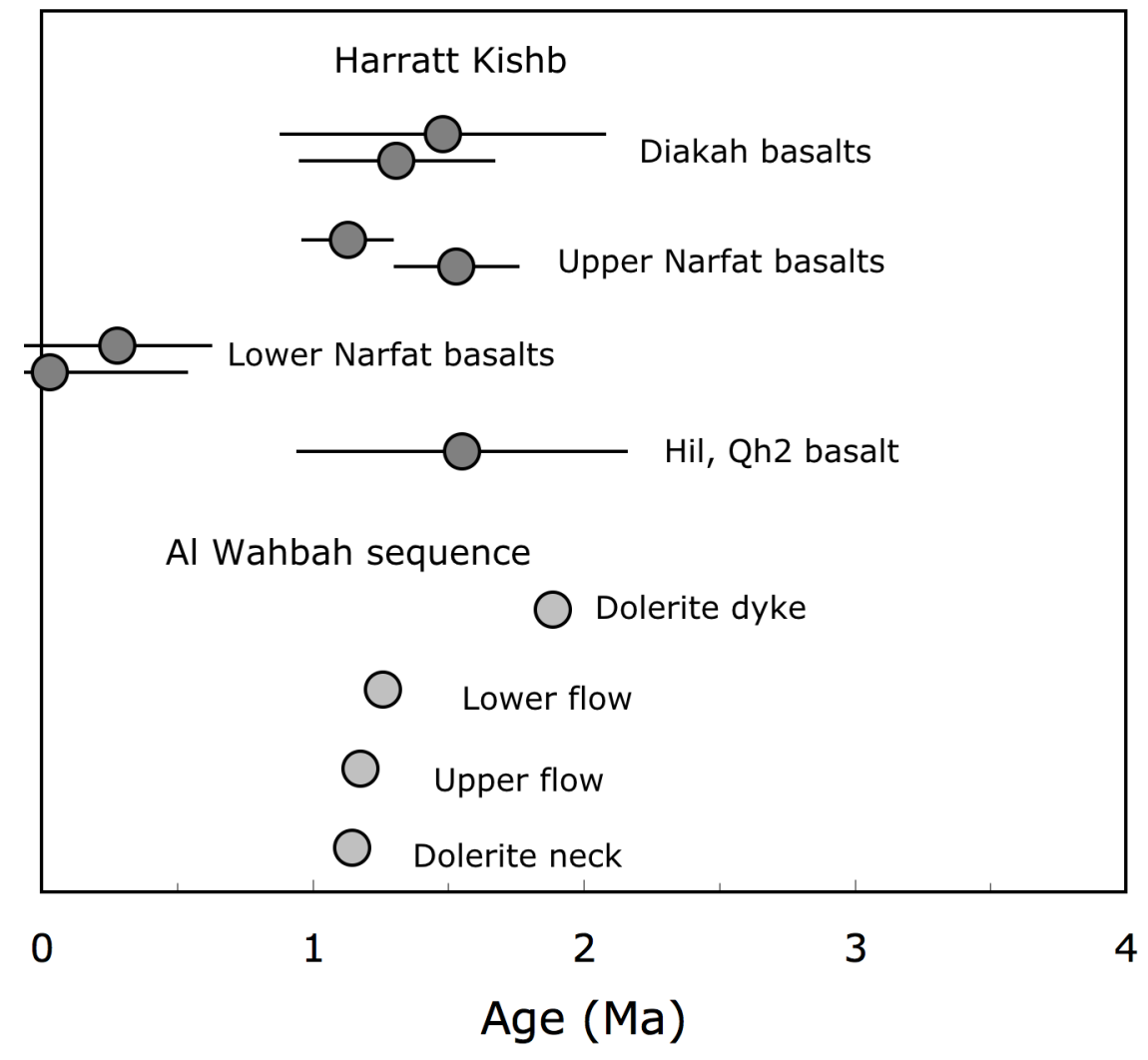

Figure 5 